2014-08

The Green Economy: Functional Domains and Theoretical Directions of

\title{
Enquiry
}

\section{Bailey, Ian}

http://hdl.handle.net/10026.1/4488

\subsection{8/a130102p}

Environment and Planning A: Economy and Space

SAGE Publications

All content in PEARL is protected by copyright law. Author manuscripts are made available in accordance with publisher policies. Please cite only the published version using the details provided on the item record or document. In the absence of an open licence (e.g. Creative Commons), permissions for further reuse of content should be sought from the publisher or author. 


\title{
The green economy: functional domains and theoretical directions of enquiry
}

\section{Ian Bailey}

School of Geography, Earth and Environmental Sciences, Plymouth University, Plymouth PL4 8AA, England; e-mail: ian.bailey@ plymouth.ac.uk

\section{Federico Caprotti II}

Department of Geography, King's College London, Strand, London WC2R 2LS, England; e-mail: federico.caprotti@kcl.ac.uk

\begin{abstract}
The green economy is a highly complex construct in terms of its attempts to integrate economic, environmental, and social concerns, the wide range of actors involved, its material outcomes, and the forms of governance needed to regulate processes of economic greening. As such, it poses new empirical and theoretical challenges for social science research on socioenvironmental futures. This paper has two main aims. The first is to survey the emergent features and functional domains of the green economy. The second is to consider theoretical tools that might be used to analyse the drivers and processes shaping the green economy. Focusing on literature on sociotechnical transitions, ecological modernisation, the 'green' cultural economy, and postpolitical governance, we argue that understanding the functional and spatial heterogeneity of the green economy necessitates a multitheoretical approach. We then explore how combining branches of research on socioenvironmental governance can lead to theoretically and ontologically richer insights into the drivers, practices, and power relations within the green economy. In so doing, we respond to calls for socioeconomic research on environmental change which is neither just empirical nor bound to one theoretical outlook to the detriment of understanding the complexity of socioenvironmental governance and human-nature relations.
\end{abstract}

Keywords: green economy, transition, sustainable development, ecological modernisation, postpolitical

\section{Introduction}

Over the past decade the 'green economy' has emerged as a major new buzzword in sustainability discourses and national development strategies globally. The United Nations' (UN) vision document, The Future We Want, describes the green economy as an economic development model that results in improved human well-being and social equity while significantly reducing environmental risks and ecological scarcities (UN, 2012). In the words of one UN expert panel, it represents nothing short of a "new economic growth paradigm" for moving from an economic system "that allowed, and at times generated crises towards a system that proactively addresses and prevents them" (Ocampo, 2011, page 3).

Whatever the merits of such claims, the green economy concept has certainly gained impressive political and business support in recent years. Five years after the launch of the United Nations Environment Programme's Green Economy Initiative in 2008, "the green economy in the context of sustainable development and poverty eradication" was made one of the two core themes of the UN "Rio plus 20" Earth Summit (UN, 2012). At the national scale the green economy has again been rapidly integrated into economic policy discourses. One UK ministerial report published in 2011 described it as a prerequisite for growth 
(Spelman et al, 2011), and in 2012 the House of Commons Environmental Audit Committee described it as a guiding concept for creating green agendas across a range of traditional and emerging sectors. Similar sentiments are evident in France, where the économie verte is again constructed as a context for green growth (Direction Régionale et Interdépartementale de l'Environnement et de l'Énergie d'Île-de-France, 2013).

There are also strong signs of the green economy becoming a touchstone for economic development in many industrialising countries. The Chinese government's Twelfth Five-Year Plan (2011-15), for example, allocates US $\$ 770$ billion of investment, scheduled for the period 2011-20, in sectors identified as part of the green economy (Loh, 2012). In Brazil "Green GDP" has been highlighted as a key development target and strategy for achieving regional and global economic leadership (Frischtak, 2011).

One striking feature of these strategies is the range of meanings being attached to the green economy, particularly the frequent use of 'growth' as a proxy for 'development'. The Organisation for Economic Cooperation and Development (OECD), for instance, has routinely deployed phrases like "green growth" and "eco-innovation" to denote a decoupling of growth from environmental depletion (OECD, 2009; 2013), whilst one of China's major green economy strategies focuses on technological innovation and renewable energy aimed at powering the country's double-digit GDP growth while mitigating the externalities associated with growth fuelled mostly by fossil fuels. Likewise, Brazil emphasises the green economy's potential in relation to valuing and protecting its ecosystem resources. Antônio Patriota, the Brazilian Minister of Foreign Affairs, summed up the situation in 2011, arguing that the green economy was "an open concept, under construction" that can be "adapted to the level of development of each country" (UNESCO, 2012).

Such fluid interpretations, that echo 'growth versus development' debates in sustainable development, have led to predictable and vociferous critiques of the green economy. Brand (2012) argues that it reproduces many of the definitional inconsistencies that have vexed sustainable development, while Spash (2012, page 95) describes the UN's vision of the green economy laid out in The Future We Want (UN, 2012), as a "red herring" for ignoring "the basic contradiction between ever-expanding human activity and a finite world". Boyd et al (2011), meanwhile, question whether the widespread focus on eco-efficiency and decoupling suggests genuinely transformative processes or simply a renewed attempt by the social forces of capital to render environmental change and sustainable development less threatening to, and even profitable for, capitalist accumulation strategies. Cook and Smith (2012) express similar unease about the limited attention given to inclusivity and social and distributive justice in mainstream readings of the green economy.

Outlining the full range of critical interventions on the green economy lies outside the scope of this paper. Nonetheless, the green economy is undeniably an ambiguous and evolving construct that provides fertile ground for critical enquiry, both of specific practices and from a broader standpoint, as green economy activities take shape and evolve across different political-economic and socioenvironmental contexts. Building on Boyd et al's (2011) concerns about the rebranding of capitalist accumulation strategies under a green economy guise, such investigations might examine the rise of the green economy in the context of the wider genealogy of neoliberalism and scrutinise the power politics shaping its identity (Peck, 2010). Scope also exists for investigating how the liberal environmentalism evident in many UN and national green economy documents is both reinforcing certain status quos and 
enabling environmental concerns to rise to a more prominent place on political agendas, even if the original goals of environmentalism are being altered in the process (Bernstein, 2002).

At the same time, it is important not to neglect questions aimed at elucidating what is, after all, an emergent and fluid phenomenon. Our argument here is that positioning and critique of the green economy require a clearer grasp of its characteristics and the processes through which ideas like green growth are being pursued. For instance: what spheres of economic and social activity currently feature most prominently in the green economy growth, and how might these change in the future? Which actor groups are involved, in what capacities, and with what motivations? How are metrics of green economic success and failure decided and adjudicated? How are state-led green economy initiatives being established and governed? What are the main economic, social, and environmental effects of the green economy, and how are its benefits and costs being distributed? Finally, how can the green economy's multiple and shifting characteristics be theorised, without overemphasising specific facets (such as individual resources or projects), to move "towards broader framings of socionatural actors in line with recent debates in cultural and environmental geography?" (Bakker, 2009, page 1786).

Accordingly, this paper has two central aims, both intended to initiate debate among social scientists about the nature of the green economy and the challenges it poses for scholars, politicians, the private sector, and activists. First, we survey the emergent features of the green economy by exploring the pressures driving its emergence, the institutional regimes supporting and governing its development, and different domains of green-economy innovation (Foxon, 2011; Rotmans and Kemp, 2008; Scrase and Smith, 2009). In following this line of enquiry, we remain heedful of Shove and Walker's (2007) warnings about the difficulties of the idea of calculated and orchestrated transitions to 'more sustainable' futures. We thus strive throughout to stress the diverse, hybrid, and fluid character of the green economy and how it is defined as much by individual sites and networks as it is by institutional steering and layered patterns of economic governance.

The second half builds on these characterisations by considering theoretical tools available to analyse the drivers and processes shaping the green economy. We argue that the green economy's functional and spatial heterogeneity necessitates a multitheoretical approach that does not privilege a single perspective or facet of green economic thought or practice. Rather, we explore how combining different spheres of research on socioenvironmental governance in geography and cognate disciplines can lead to theoretically and ontologically richer insights. In this manner, we respond to Castree's (2008) call for research on socioenvironmental change which is neither just empirical nor bound to one theoretical outlook to the detriment of understanding the complexity of socioenvironmental governance and human-nature relations.

\section{Geographies of the green economy}

\section{The organisation and functional domains of the green economy}

An obvious starting point for probing the green economy is to examine its organisation at the international, national, regional, and local levels. At the international level, reorienting economic activity will require new multilateral institutions and the 'reprogramming' of existing ones such as the World Trade Organisation (WTO) to provide political support, strategic coordination, and assistance for new technologies and business and user practices (Foxon, 2011). However, the Chinese and Brazilian examples mentioned earlier suggest that much of the green economy's strategic direction will be defined by national policies and networks of international, state, subnational, and nonstate actors seeking to capitalise on 
opportunities offered by green economy agendas. The likely result of this blend of government-led green-economy strategies and 'private regimes' will be a mosaic of practices that displays both synergistic components and dysfunctional overlaps and which has hazy systems of accountability for ensuring consistency between higher level visions of the green economy visions and on-the-ground green-economy strategies (Ostrom, 2010).

Examining physical sites of green-economy activity at the local and regional levels, meanwhile, helps to move away from managerialist perspectives of economic transition by focusing attention on the politics of the green economy as regions, cities, and companies compete to host emerging sectors or to emulate others' successes (Shove and Walker, 2007). Such processes will inescapably produce winners, losers, and uneven development as regions specialise or are outcompeted in the factors of green economic production. Conflicting visions of the green economy-stressing global or local issues and social, economic, and environmental benefits in different measures-will also surface as regional governments, businesses, and communities decipher the concept through the lenses of their beliefs, traditions, and dilemmas (Krueger and Gibbs, 2009).

Whilst organisational layering approaches such as these provide useful insights into the general arenas in which the logics, discourses, and practices of the green economy will be deliberated, they offer a somewhat unrefined view of the motivations of its major actors and the types of processes that are likely to influence its operation. A more helpful approach may therefore be to consider the green economy as a series of functional domains in order to probe the actors and forces shaping the involvement of international organisations, national and regional governments, and nonstate actors in the green economy (table 1).

Table 1. Functional domains in the green economy.

\begin{tabular}{ll}
\hline Functional domain & Characteristics \\
\hline Financial & $\begin{array}{l}\text { Green economy as global financial opportunity } \\
\text { Risk management } \\
\text { Transitional policies } \\
\text { Institutional }\end{array}$ \\
& $\begin{array}{l}\text { Regional regeneration and competition } \\
\text { Regulatory }\end{array}$ \\
& $\begin{array}{l}\text { Harnessing innovation (green intellectual property and patenting) } \\
\text { New geographies of production and consumption }\end{array}$ \\
& Radical, transitional, and oppositional movements \\
\hline
\end{tabular}

The green economy's financial domain, broadly conceptualised, encompasses the economic opportunities and risks engendered by the drivers and market developments associated with the green economy as financiers and private investment bodies seek out 'green' investments. In this sense, the green economy closely resembles the emergence and intensification of more specific sectors and regions, such as cleantech, and emerging markets and national economies (Caprotti, 2012; Kose and Prasad, 2010; Sidaway and Bryson, 2002). At the same time, the identification of new financial opportunities brings renewed concerns about approaches to risk when economies, regions, and sectors are faced with potential sociotechnical change. Such risks do not relate solely to participation in the green economy, but also affect decisions on the timing of entry and the consequences of nonparticipation. For example, significant risks exist in terms of the potential stranding of existing capital assets as new technologies are 
embraced, consumption trends shift, and old markets wither. Such risks will become increasingly pertinent to companies, investors, and countries that have stressed gilt-edged 'carboniferous' investments over unproven markets (Vesilind et al, 2006).

These considerations point towards the green economy's institutional domain, and the various local, regional, state, and international actors interested in 'plugging in' to the green economy and utilising environmental technologies, industries and the "green" service sector to diversify away from carbon-intensive economies. Such initiatives are often multiscalar: for example, the Sino-Singapore Tianjin Eco-City within the Tianjin-Binhai New Area in China involves institutional actors from across the decision-making spectrum, from the Chinese and Singaporean premiers; provincial political actors (Tianjin municipality and Singapore's Housing and Development Board); municipal actors (planning offices and institutes within Tianjin Municipality), and state-affiliated bodies such as the China Academy of Urban Planning (Caprotti, 2014). By definition, this institutional domain is highly variegated across initiatives and countries. At the state level, for example, countries such as China exhibit a greater tolerance for 'green risk' than economies heavily dependent on fossil fuel exports, such as Australia - which, ironically, depends on sustained Chinese demand for these resources.

At the same time, the incorporation of green economy ideas into development strategies focuses attention on the green economy's regulatory domain and the creation of standards and agreements through which benchmarks and common 'ways of doing' green business can be evaluated. Different sets of metrologies, linked to specific sectors, can be explored as part of investigations into this domain (Slater, 2002). For example, the UN's pre-Rio+20 discussion papers identify a series of interscalar regulatory challenges facing the green economy (Ocampo, 2011). The first stresses the need for governments to support 'desirable' activities and oversee the contraction of 'outmoded' activities through the application of green-growth 'standards' and policies promoting innovation and the diffusion of new technologies and techniques. A second set of regulatory challenges centres on the rules governing interactions between states. Concerns here include sharing the benefits of technological change while protecting intellectual property rights, and ensuring standards and subsidies for emergent sectors are not used for protectionist purposes that obstruct developing countries from gaining footholds in the green economy (Ocampo, 2011). The evidence indicates that most early innovation will occur in industrialised countries, with intellectual property and patents being held by major national and transnational companies. The potential thus exists for imbalances in where and on what terms new technologies are deployed. Clear ethical arguments exist for bilateral and multilateral regulation to prevent technological disparities reinforcing existing economic inequalities; yet questions remain about how policies aimed at greater transnational equity will be developed and enforced by bodies such as the WTO.

Examples of more fluid elements of the regulatory domain include the ISO14001 environmental management system and the use of green building standards under the Leadership in Energy and Environmental Design (LEED) certification programme (Cidell, 2009). Under LEED, negotiated standards provided a way for institutional and corporate actors to establish norms for green building services, while the crystallisation of common standards gave the justification for a new green building economy. Thus, as the US Green Building Council (2011) states: 
"LEED buildings command rent premiums of $\$ 11.33$ per square foot over their nonLEED peers and have 4.1 percent higher occupancy. Rental rates in Energy Star buildings represent a $\$ 2.40$ per square foot premium over comparable non-Energy Star buildings and have 3.6 percent higher occupancy."

The link with the green building economy created by LEED certification is echoed by corporate actors. In an interview with The New York Times, the CEO of Skanska Group, an international project-development and construction company, highlighted the drivers behind its move into new headquarters in the Empire State Building:

"The space is LEED platinum. Green actually saves you money as long as you look in terms of life cycle, like any investor would. We save about 50 percent of our energy here over what we spent at our former space on Madison Avenue, which was about the same size" (McNally, quoted in Marino, 2011).

The standards and metrologies established by institutional and other actors not only constitute regulatory and institutional domains through which the green economy makes sense, it also creates logics for interaction between public and private sector entities aimed at establishing new targets for demand in green economy services and products.

This leads to the most diverse and porous of the functional domains: the green cultural economy. This domain can be envisaged at the macrolevel as an arena for analysing new 'green' modes and geographies of production and consumption. Whilst the green economy first emerged as an identifiable concept in the 1980s and 1990s focusing on the use of price mechanisms to ameliorate environmental externalities (eg, Pearce et al, 1989), its latest incarnation aspires to create whole new orientations for capitalism. This 'new' green economy that now spans international arenas, carbon offsetting, emerald advertising, green iPhone apps, and renewable energy thus needs to be understood as a functional domain in its own right encompassing the multitude of production and consumption practices implicit in a reform(ulat)ed capitalism.

The diversity of the green cultural economy is highlighted in the brands of consumerism that different branches and spaces of the green economy might prioritise. A first category involves consumption of broadly similar products, but with reduced harmful socioecological impacts through the adoption of resource-efficient production processes. A second category encompasses deeper shifts in the types of product sold and greater emphasis on green economy branding (eg, fair-trade or organic), but with a continued commitment to consumerism. A third, echoing green radical thought, entails quantitative reductions in demand, although this is more difficult to reconcile with the rekindling of economic growth and development goals stressed by many of the green economy documents reviewed earlier.

However, the green cultural economy encompasses not only products, services, cultures, and economic drivers but also oppositional and radical movements which, by reacting to the green economy, contribute to defining its meanings and practices. The diversity and viral nature of such social movements are illustrated by the Transition Network, a UK-based initiative promoting economic relocalisation in response to concerns about climate change, peak oil, and the erosion of community resilience by globalisation and the financial crisis. Since 2007 this movement has grown from a single-town initiative in Totnes in the UK into an international network of over 1000 initiatives, each largely self-steering in defining their goals and the initiatives adopted. Most initially centred on areas such as local food, 
sustainable construction, and local currencies but some have more recently branched out into social enterprise and the creation of 'parallel public infrastructure' to supplement (and, in the eyes of its architects, replace) existing institutions (Bailey et al, 2010).

It is important to note that, in categorising the green economy into functional domains, our intention is not to imply artificial dividing lines between them. For example, the social networks involved in the financial green economy and its interactions with governing institutions include not only regulatory and institutional interactions but also relational economic geographies with their own cultural components (Berndt and Boeckler, 2009). Our purpose is simply to draw attention to the different areas of green economy activity as a first step towards surveying the options for theorising the green economy's practices, motivations and consequences.

The next section considers a range of theoretical possibilities offered by existing socialscience research on socioenvironmental governance. The discussion begins by arguing for a multitheoretical approach to the analysis of the green economy. It then examines descriptive theorisations for understanding the nature of change processes arising from the green economy, drawing on the sociotechnical transitions and transition theory literatures. Following this, the discussion focuses on explanatory theorisations, utilising ecological modernisation and discourse theories to explore the mechanisms through which certain conceptions of the green economy's goals and modi operandi are defined, embedded, and contested within and across its functional domains. Attention then turns to more critical theorisations, focusing particularly on debates about the potential for green-economy logics to encourage a postpolitical approach to future human-environment relations. We do not claim that these theoretical avenues are either comprehensive or uncontested; however, we have tried to follow a logical progression that seeks first to understand the workings of the green economy idea and to explain the forces shaping its orientations before engaging in more critical examination of its implications.

\section{Developing a multitheoretical approach to the green economy}

In the previous sections we argued that the green economy is a guiding logic through which a variety of functional domains, sectors, practices, and physical spaces of green economic activity are being organised, rather than a monolithic entity. Theoretical analysis of its characteristics must reflect this diversity by employing a range of perspectives while simultaneously examining potential linkages between them.

The advantages of a multitheoretical approach can be illustrated by considering cleantech investment, one element of the green economy's financial domain. Since 2001 over US \$1 trillion of funds have flowed into cleantech investment, with US \$250 billion being committed in 2010 alone (SAM Group, 2011). The profile of investors has also broadened and by 2012 included not only banks and private equity but also institutional investors and governments. For example, the UK Universities' Superannuation Scheme (USS) includes a US \$250 million cleantech fund (USS, 2011) and, in 2011, the World Bank announced a US $\$ 60$ million venture-capital-like fund aimed at fostering small cleantech companies (Reuters, 2011). The largest cleantech funds are nevertheless run by investment corporations. In 2011 Riverstone LLC ran US \$685 million in cleantech funds, while Generation Investment Management LLP held US \$683 million in cleantech investments. By 2007 cleantech startups were overrepresented among total initial public offerings backed by venture capital across all sectors, while overall in the period 2005-11 US \$50 billion was raised in 293 cleantech IPOs, with Asian markets accounting for 67\% of capital raised in 2010 (SAM Group, 2011). Alongside demonstrating the rapid growth of cleantech investment, the 
example illustrates several ways in which aspects of the green economy might be conceptualised. For example, ecological modernisation perspectives help us to understand how cleantech funds are facilitating flows of capital, technologies, and knowledge within a largely neoliberal framework. Transition theory perspectives complement this by probing cleantech funds as a component of transitional processes towards low-carbon futures, while discourse approaches enable interrogation of the vocabularies and discursive arenas contributing to the materialisation of cleantech funds as vehicles for green investment. Finally, cultural economy approaches focus attention on the construction of markets and the wider social and cultural formation of the green economy.

\section{Sociotechnical transitions towards a green economy}

At the heart of the green economy concept lies the idea of a broad-based transition towards more sustainable, just, and resilient economies. The sociotechnical transitions literature provides an obvious starting point for examining the transitional processes shaping the green economy at its landscape, regime, and niche 'scales' (Scrase and Smith, 2009). Building on this typology, the green economy can be interpreted as responding to a string of landscape pressures influencing "the broad political, economic and institutional contexts within which socio-technical regimes are situated and evolve" (Berkhout et al, 2009, page 223). The green economy can in turn be interpreted as a landscape response to these pressures that seeks to synchronise growth, environmental stewardship, and equity through innovation, technology diffusion, and reformed trade and economic relations (Ocampo, 2011). Sociotechnical regimes similarly signify the dominant practices, rules, and technologies that provide stability and reinforce prevailing sociotechnical systems across the functional domains of finance, institutions, regulation, and the cultural economy, whilst the various domains and physical spaces of green-economic activity can be likened to sociotechnical niches seeking to influence or replace incumbent regimes. For example, cleantech investment forms a part of the green economy financial domain, which in turn constitutes one element of the wider financial sector; WTO rules relating to green economy measures constitute a component of the wider institutional and regulatory regime for international trade; and fair trade certification forms a niche within general consumption regimes.

Utilising the analytical devices of transitional landscapes, regimes, and niches provides a useful toolkit for examining the causal agents and mechanisms through which individual green economy sectors, domains, and geographical spaces seek to influence or supersede existing regimes (table 2). Following Geels's (2010) reasoning, niches may expand their influence in a variety of ways, including conscious conflict and power struggles, network interactions, evolutionary experimentation, or a mixture of mechanisms. 
Table 2. Causal agents and mechanisms of change processes (adapted from Geels, 2010, page 497).

\begin{tabular}{|c|c|c|}
\hline & Causal agent & Causal mechanism \\
\hline Rational choice & Individual, self-interested actors & $\begin{array}{l}\text { Decentralised choice by instrumental } \\
\text { rationality }\end{array}$ \\
\hline Evolution & Agents in population & Variation, selection, retention \\
\hline Structuralism & Core belief systems & $\begin{array}{l}\text { Deep structures operate, influencing } \\
\text { actors' views and preferences }\end{array}$ \\
\hline $\begin{array}{l}\text { Interpretivism/ } \\
\text { constructivism }\end{array}$ & $\begin{array}{l}\text { Individual actors with varying ideas } \\
\text { and interpretations }\end{array}$ & $\begin{array}{l}\text { Social interaction, construction of } \\
\text { shared meaning, sense-making, } \\
\text { learning, debate }\end{array}$ \\
\hline Functionalism & Social system & $\begin{array}{l}\text { Actors fulfil system needs, enacting } \\
\text { rules, tasks, and norms }\end{array}$ \\
\hline $\begin{array}{l}\text { Conflict and power } \\
\text { struggle }\end{array}$ & $\begin{array}{l}\text { Collective actors (groups, classes) } \\
\text { with conflicting interests }\end{array}$ & $\begin{array}{l}\text { Conflict and power struggle between } \\
\text { different agent groups }\end{array}$ \\
\hline Relationism & Networks and ongoing relations & $\begin{array}{l}\text { Interaction, coconstruction, translation, } \\
\text { alignment }\end{array}$ \\
\hline
\end{tabular}

(adapted from Geels, 2010, page 497)

Sociotechnical transitions perspectives might be further employed to explore meta-level forces shaping the green economy: for instance, using scenario-building exercises. A similar approach is utilised by Newell and Paterson's (2010) examination of capitalism in a climatechange-altered world. Their first scenario, neoliberal utopia, imagines a situation in which markets and institutional investors facilitate a smooth decoupling of growth from environmental degradation through large-scale investment strategies in renewable energy and eco-efficiency measures. Stagnation offers a more pessimistic prognosis, where failed attempts at international cooperation and poorly functioning environmental markets lead to cynicism and fatalism, with rich countries investing heavily in adaptation and lifeboat-style resilience building, and the poor are left to fend for themselves. Their third scenario, decarbonised dystopia, envisages mass deployment of geo-engineering, biofuels, nuclear power and other environmental management tools to provide technological fixes but with high risks to health and food supply and unexpected side effects. Their fourth scenario, environmental Keynesianism, is characterised by stronger governmental supervision of markets and systemic investments in transportation and energy infrastructure.

However, the utility of transitions management perspectives depends partly on how far the green economy represents an intentional shift in economic orientations and practices or a series of immanent processes that lack premeditation, coordination, or identifiable destinations (Foxon, 2011). Here opinion divides between those who are more optimistic about the possibility of iterative, but purposeful, steering of technological and governance innovation and those who question the more managerialist aspects of the multilevel perspective (Shove and Walker, 2010). The multidimensional, multiscalar, and multilocational nature of the green economy, the range of actors involved, and the lack of undisputed chains of command between the green economy's domains all militate against the idea of planned transitions except at very high levels of abstraction. As Bailey and Wilson (2009) argue, the transitional processes associated with the green economy may be more aptly viewed as an ongoing contest between alternative economic visions in which clear or stable end points do not exist. 
Similarly, institutional 'steering' by governments and international organisations has so far consisted mainly of creating incentives and ground rules for green economy activities rather than direct intervention to ensure particular outcomes are achieved. Equally, recent trends in other areas of environmental governance suggest that the green economy is likely to be characterised by hybrid forms of governance in which nonstate actors play key roles in defining and establishing green economy initiatives alongside government regulatory infilling to correct more blatant 'market failures' and undesired trends, rather than by more intentional transitional processes.

\section{Green-economy discourses and the cultural green economy}

Whilst sociotechnical transitions perspectives provide useful insights on the green economy's structural features and the mechanisms through which individual sectors, domains, and niches might influence existing political-economic regimes, attention also needs to be paid to the discourses shaping the rhetorical and material construction of the green economy. As Dryzek (2013) argues, discourses are important in conditioning the perceptions and values of others towards particular interests, especially in situations where more formal sources of coordination are weak or absent. Analysis of key green-economy discourses may thus yield important insights into how different ideas about future economic orientations and practices are constructed, and how these contribute towards the future shape of the green economy and power relations within and between its domains. One particular arena of debate concerns the stance taken by different actors towards the concept of ecological modernisation and the types of institutional, market, and social reform that might catalyse a more harmonious or even mutually reinforcing relationship between economic development and environmental protection (Fieldman, 2013). Beyond the general optimism towards the prospect of more sustainable capitalism inherent in ecological modernisation, sharp divisions emerge between weak ecological modernisation discourses that emphasise the ability of existing institutions and growth-centred economic systems to adapt to environmental imperatives through the reorientation of capital flows, technologies, and knowledge towards greater eco-efficiency (UN, 2012), and strong ecological modernisation discourses that stress the need for more radical institutional, market and social reforms and more pluralistic decision making to mediate between ecological, development, and economic concerns (Christoff, 1996).

Similar discursive tensions can be found between advocates of liberal environmentalism that favour the use of markets and property rights to internalise pollution costs and conserve resources, and those that support more regulatory and even anti-capitalist, antigrowth perspectives (Bernstein, 2002). Whether weaker or stronger ecological modernisation discourses, or those favouring or opposing liberal environmentalism, ultimately come to characterise the green economy will almost certainly be unprovable at an aggregate level. Our concern is less with philosophical debates on either discourse, and more with how examining competing normative and distributional visions of the green economy helps to illuminate the processes by which the green economy is negotiated within and between its various actors and functional domains. Such perspectives may also shed light on how environmentalism and social justice are incorporated into 'norms' of green growth, and how different actors resist elements of this norm whilst retaining general allegiance to its potential.

One might speculate that the financial domain will prioritise weak ecological modernisation because of its alignment with traditional market concerns and risk evaluations. Massconsumer elements of the cultural economy may also prioritise improved eco- and social 'efficiency' in the context of existing modes of production and consumption. The discursive tendencies of the regulatory and institutional domains are slightly trickier to predict, though 
probably not too much so. There are certainly few signs of existing regimes moderating their support for economic growth as the major measure of societal well-being, particularly since the 2008 financial crisis. However, their regulatory functions may encourage greater reflection on the goals and processes of the green economy, and stimulate a willingness to intervene to correct social and ecological deficits created by weak ecological modernisation strategies.

What this suggests above all is that rule setting and financial power within the green economy are overwhelmingly stacked towards coalitions that generally favour weaker and more neoliberal approaches to ecological modernisation. Whilst this is not surprising given that the green economy is, in many ways, an artefact of existing institutions and ways of thinking, it sharpens the focus on the task facing those seeking more radical change and on the need for greater scrutiny of the strengths and weaknesses of dominant discourses against the broader ambitions of the green economy.

A good case in point is the current emphasis on environmental markets as a preferred method for promoting 'eco-efficient' environmental and natural resource management (Bernstein, 2002). Here, geographical literature on the commodification of nature provides a strong basis for scrutiny of liberal environmentalism as a norm and core modus operandi of the green economy (Castree, 2002). Recent scholarship in this area includes studies of 'cap-and-trade' and other markets for greenhouse gas emissions, sulphur dioxide, fisheries, water, forests, and wetlands (Prudham, 2004; Robertson and Hayden, 2008). A common finding is that attempts to commodify entities whose commodity status is not intrinsic can produce a range of physical and ethical difficulties (Boyd et al, 2011). Among the main problems identified are the difficulties of converting different components of nature into measurable and commensurable units and in establishing reliable baselines and improvement targets (Bumpus, 2011; Robertson and Hayden, 2008). Additionally, such markets have often proven susceptible to distortions caused by: concentrations in market power; information asymmetry between regulators and regulated parties; monitoring and enforcement difficulties; and the failure of instruments like the Clean Development Mechanism to deliver development benefits where financial flows are attracted to more profitable projects rather than areas of greatest need (Newell and Paterson, 2010).

If environmental markets have proven problematic for individual (or more obviously connected) phenomena such as forests and greenhouse gases, commodification processes connected to the green economy may be even harder to connect to the material goals they seek to represent because of the sheer diversity of environmental and other sustainability objectives involved and the range of scales and issues over which green economy commodification systems must operate (atmosphere, water, land and resources, technologies, industrial processes, worker rights, gender relations, etc). Establishing benchmarks for measuring progress towards a green economy may therefore be extremely difficult, whilst further difficulties may arise if some sustainability goals are discarded or seen as ancillary to the core logics of liberal environmentalism. Probing the construction and enactment of such logics from the micro to macro scales, across the green economy's functional domains, and between countries thus remains an essential task for enquiries on the green economy.

Understanding the influence of discourses on the green economy also requires attention to alternative and cultural-economy discourses that help to shape its identities, and to the discourses of 'mainstream' actors in reaction to these alternatives. Despite the undoubted challenges of capturing and synthesising the multitude of discourses surrounding the green 
economy, recent research on the cultural economy and diverse economies offers some interesting avenues for further probing of the networks, discursive arenas, conventions, and knowledge-sharing processes involved in creating recognised ways of thinking and acting around specific technologies, industrial processes, and practices (Gibson-Graham, 2008). Recent work in this area includes research on: the social construction of new and emerging markets (Hughes, 2007; Lai, 2006), cleantech, and carbon offsets (Lansing, 2012); while other studies have analysed the creation of industry standards (Barry, 2006), the normative dimensions of financial markets (Hall, 2010), identity-based strategies to promote international financial centres (Engelen and Glasmacher, 2011), and patterns of ethical investment (Winnett and Lewis, 2000). What links these studies is a shared appreciation of the limits to understanding economic processes imposed by "the discursive erasure [of] neoliberal theory" and other structural approaches, and the consequent need for deeper exploration of how socioeconomic and sociotechnical constructs like the green economy are constituted and contested through social as well as power relations (Gibson-Graham, 2008, page 620).

Understanding the cultural green economy is also crucial to analysing the coevolution of discursive constructions and the material outputs of the green economy. As Berndt and Boeckler (2012, page 199) note, sensitivity to the green economy's cultural characteristics enables it to be considered as a "market socio-technical" construct, where market devices (broadly understood, from pricing mechanisms to standards frameworks) and "economistsacademic economists, business experts, and 'economists in the wild' - play a fundamental part in shaping, designing, and formatting marketization." Considering the green-economy project this way again emphasises not just its material elements, but also the interpretations and socialities which contribute to the formation of green-economy identities and paradigms.

This in turn facilitates critical interrogation of links between these social relations and the ecologically modernising and neoliberal character of mainstream discourses and their premise that capitalism and industrialisation can be made more environmentally friendly through regulation, investment, and trade (Bäckstrand and Lövbrand, 2007).

\section{Political arenas and postpolitical logics}

The preceding sections identified a range of critiques of the prevalence of weak ecological modernisation and (neo)liberal environmentalist narratives in mainstream green-economy discourses and their apparent lack of attention to social and distributive justice (Brand, 2012; Cook and Smith, 2012). Such concerns draw attention to the importance of examining wider debates on power relations within the green economy and the political logics of sustainability governance. These debates are based around apprehensions about the emergence of a postpolitical logic in sustainability governance whereby "techno-managerialist discourses and practices" (Cook and Swyngedouw, 2012, page 1962) predicated on a manufactured politics of consensus produce a depoliticising effect on debates over economic-environmental policies and development. From one perspective, the green economy's conceptual fuzziness and the heterogeneity and fluidity of its functional domains provide rich arenas for debate on the style and substance of the green economy. Cochrane (2010) adds that the recent proliferation of private and international networks engaged in governing sustainability issues further destabilises claims about an emergent but persistent trend towards consensus-based and postpolitical environmental governance. Alternative lines of reasoning, however, suggest that the sorts of mainstream green-economy narratives being articulated by the UN, OECD, and many governments could be regarded as reinforcing a consensual view of the green economy that stifles political debate on alternative socioenvironmental futures in favour of "a 
moral crusade for a more energy-selective and carbon-sparse code of socio-economic conduct" (Swyngedouw 2009, page 602) and narrow visions of what the green economy could and should mean. Indeed, in the aftermath of the Rio+20 Conference, several NGOs started questioning the growth-centred and largely neoliberal agendas that appeared to be taking shape under the 'green-economy' identity. As the Green Economy Coalition, a grouping of NGOs, research institutes, UN organisations, businesses, and trade unions argued:

"We all fought hard to get green, fair and inclusive economy understood and owned by the global community at Rio - only to see a 'growth' agenda replace it before we have drawn breath. Green growth needs to tackle environmental limits because growth that does not recognise its roots will turn into a cancer. Equally, green growth must help the world's poorest or it will be corrupted by greed to serve only the wealthiest" (Greenfield, 2012).

This is not to prejudge ourselves whether the green economy is a postpolitical or intensely political construct but, rather, to focus attention on how a 'mainstreaming' of certain brands of green-economy thinking could contribute to the marginalisation of debates on alternative economy-environment relationships (Bailey and Wilson, 2009). Swyngedouw (2009, page 604) argues that such postpolitical approaches are symptomatic of "a neoliberal governmentality that has replaced debate, disagreement and dissensus with ... technologies of governing that fuse around consensus, agreement, accountancy metrics and technocratic environmental management" and that downplays political interventions in favour of populist and moralistic strategies (also Swyngedouw, 2010), juridical primacy (Mouffe, 2005), and technocratic governance. Garsten and Jacobsson's work on corporate social responsibility certainly emphasises how ecologically modernising approaches to corporate activities have operated "by taking what is essentially a political problem, removing it from the realm of political discourse and recasting it in neutral language" (Garsten and Jacobson, 2007, page 152). Conversely, McCarthy (2012) questions whether postpolitical environmental politics are necessarily consensus driven and technocentric. On the basis of an analysis of the effects of the 2008 financial crisis on environmental politics in the US, McCarthy argues that environmental politics remained characterised by intense contestation of government produced scientific knowledge.

Further exploration of the green economy's political and postpolitical attributes thus provides an important avenue for helping to unpack its ambivalent characteristics and for critically examining what could be termed 'green fetishism' within the green economy (Walker and Shove, 2007). At the level of retail commodities, for example, "so-called 'green consumerism' can reduce the politics of climate change to the size of a Green consumer product" (Redclift, 2009, page 382), leaving the underbellies of 'green' production ignored or obscured in the general allegiance to a 'common-good' vision. Thus, while some green-economy thinking highlights cleantech, enlightened self-interest among "green" financiers and green consumerism, it also conceals a swarm of issues, from the plight of islanders threatened by sea-level rise to regions left behind in the race to develop and market 'green solutions', the power politics of energy security, and the realities facing those who will benefit least from the green economy. As Redclift (2009, page 383) argues, "Perhaps, in the 'post-political' world 'consensus', democracy and governance need to be rethought, to take account of new forms of power, and the political economy of the withdrawal from carbon dependence needs to be analysed, rather than evangelized." 
It is beyond the paper's scope to examine the politics of the green economy in detail. However, a number of questions can be suggested to provoke further empirical and theoretical debate about the political dimensions of the green economy. What are the main forces propelling apparent consensuses around the green economy as a response to environmental, social, and economic problems? Through what processes have greeneconomy logics become institutionalised and diffused across geographical spaces, arenas of governance and functional domains? To what extent can the green economy genuinely be regarded as postpolitical governance or as creating arenas for debates that reenergise environmental politics? In what ways and by whom are its discursive logics being challenged and reformulated? And what are the implications of a postpolitical green economy for equity and attempts to address wealth disparities and uneven power relations in the global economy?

\section{Conclusion}

The green economy has attracted high levels of political, business, and academic attention in recent years as a guiding logic for improving social well-being and equity while significantly reducing environmental risks and ecological scarcities. Despite these impressive ambitions, it has already come under sustained attack for failing to confront the socioecological contradictions of capitalism and for attempting to commodify nature in ways its critics believe will amplify existing global inequities and power relations (Brockington, 2012). Well reasoned as these critiques might be, our contention is that academic analysis needs to pay greater attention to understanding the conceptual complexities and diverse realities of the green economy before pronouncing judgment on whether or not it represents an important step towards sustainability or a cynical attempt to defend current capitalist systems. The essence of our argument is that green economy is not a monocultural project. Rather, it is an evolving and ambiguous logic that incorporates a multitude of meanings and practices within and across its various material spaces and functional domains. Scrutiny of the green economy needs to begin by developing clearer understandings of its structures and practices and the discourses shaping its identities and trajectories.

We have attempted to do this by examining the organisation of the green economy and by identifying a series of functional domains that help to shed light on different facets and relationships that make up the wider concept of the green economy. These descriptive understandings were used as a basis to explore theoretical perspectives that might aid in making greater sense of the green economy. Here we argued that deciphering and scrutinising the green economy requires a multitheoretical approach that reflects its diversity and that draws on different strands of research on socioenvironmental governance rather than privileging particular - and necessarily selective-perspectives. In keeping with the UN vision articulated at Rio+20, we began by examining the green economy as a multilevel transitional process, drawing on insights from the sociotechnical transitions literature.

Although such perspectives can become problematic where they view the green economy as a premeditated and orchestrated process, the analytical devices of transitional landscapes, regimes, and niches provide a useful toolkit for examining the causal agents and mechanisms through which individual green-economy sectors, domains, and geographical spaces seek to influence or supersede existing regimes. Following this, we examined the benefits of investigating the green economy from discourse and cultural-economy perspectives in order to deepen understandings of how ideas such as ecological modernisation and commodification are influencing green-economy thinking, and are resisted by adherents of alternative socioenvironmental discourses. Such approaches, we argue, offer useful inroads 
into how different sets of actors (individually and through interaction) are constructing and performing green-economy 'identities'.

Finally, we examined more critical theorisations of the green economy and ongoing debates about consensus-driven, postpolitical approaches to social and environmental governance. Whether the green economy really represents the engineering of a 'conflict-free' politics of transition through the consolidation a unifying vision - "the future we want" (UN, 2012) - or whether, as Raco and Lin (2012) suggest, its multidimensionality provides fertile new arenas for debate between alternative socioeconomic futures remains an open question. Returning to our earlier argument, the green economy's depoliticising tendencies must be judged through examination of its discourses, power structures, networks, and on-the-ground practices rather than the unreliable evidence of high-level political declarations.

The directions examined represent our attempt to explore how drawing together different theoretical strands can contribute towards a more nuanced and empirically informed understanding of the green economy. We make no claims to completeness and recognise that many other theoretical perspectives can contribute fruitfully to debates on the green economy. Our broader aspiration is to encourage a wide-ranging and open debate among social scientists about what the green economy is, what it represents, and the transformative processes being enacted under its auspices: not necessarily for the purpose of supporting or condemning it, but in appropriate recognition of its likely significance for the global economy and sustainable development.

\section{References}

Bäckstrand K, Lövbrand E, 2007, “Climate governance beyond 2012: competing discourses of green governmentality, ecological modernization and civic environmentalism", in The Social Construction of Climate Change: Power, Knowledge, Norms, Discourses Ed. M E Pettinger (Ashgate, Aldershot, Hants) pp 23-48

Bailey I, Wilson G, 2009, "Theorising transitional pathways in response to climate change: technocentrism, ecocentrism, and the carbon economy" Environment and Planning A $\mathbf{4 1}$ 2324-2341

Bailey I, Hopkins R, Wilson G, 2010, "Some things old, some things new: the spatial representations and politics of change of the peak oil relocalisation movement" Geoforum 41 595-605

Bakker K, 2009, "Neoliberal nature, ecological fixes, and the pitfalls of comparative research" Environment and Planning A 41 1781-1787

Barry A, 2006, “Technological zones” European Journal of Social Theory 9 239-253

Berkhout F, Angel D, Wieczorek A J, 2009 “Asian development pathways and sustainable socio-technical regimes" Technological Forecasting and Social Change 76 218-228

Berndt C, Boeckler M, 2009, "Geographies of circulation and exchange: constructions of markets" Progress in Human Geography 33 535-551

Berndt C, Boeckler M, 2012, "Geographies of marketization”, in The Wiley-Blackwell Companion to Economic Geography Eds T J Barnes, J Peck, E Sheppard (Wiley-Blackwell, Oxford) pp 199-212

Bernstein S, 2002, "Liberal environmentalism and global environmental governance" Global Environmental Politics 2 1-16 
Boyd E, Boykoff M, Newell P, 2011, “The 'new' carbon economy: what's new?” Antipode 43 601-611

Brand U, 2012, "Green economy - the next oxymoron? No lessons learned from failures of implementing sustainable development" GAIA-Ecological Perspectives for Science and Society $2128-32$

Brockington D, 2012, “A radically conservative vision? The challenge of UNEP's Towards a Green Economy" Development and Change 43 409-422

Bumpus A, 2011, "The matter of carbon: understanding the materiality of tCO2e in carbon offsets" Antipode 43 612-638

Caprotti F, 2012 "The cultural economy of cleantech: environmental discourse and the emergence of a new technology sector" Transactions of the Institute of British Geographers, New Series 37 370-385

Caprotti F, 2014 "Critical research on eco-cities? A walk through the Sino-Singapore Tianjin Eco-City, China" Cities 36 10-17

Castree N, 2002, "Commodifying what nature?" Progress in Human Geography 27 273-293

Castree N, 2008, "Neoliberalising nature: processes, effects, and evaluations" Environment and Planning A 40 153-173

Christoff P, 1996, "Ecological modernisation, ecological modernities" Environmental Politics 5 476-500

Cidell J, 2009, "Building green: the emerging geography of LEED-certified buildings and professionals" The Professional Geographer 61 200-215

Cochrane A, 2010, "Exploring the regional politics of 'sustainability': making up sustainable communities in the South-East of England" Environmental Policy and Governance 20370 381

Cook I R, Swyngedouw E, 2012, "Cities, social cohesion and the environment: towards a future research agenda” Urban Studies 49 1959-1979

Cook S, Smith K, 2012, "Green economy and sustainable development: bringing back the social" Development 55 5-9

Direction Régionale et Interdépartementale de l'Environnement et de l'Énergie d'Île-deFrance, 2013 Économie verte et equitable, http://www.driee.ile-de-france.developpementdurable.gouv.fr/economie-verte-et-equitable-r516.html

Dryzek J, 2013 The Politics of the Earth: Environmental Discourses (Oxford University Press, Oxford)

Engelen E, Glasmacher A, 2011, "Multiple financial modernities: International Financial Centres, urban boosters and the internet as the site of negotiations" Regional Studies, http://dx.doi:10.1080/00343404.2011.624510

Environmental Audit Committee, 2012 A Green Economy: Government's Response to the Committee's Twelfth Report of Session 2010-12 HC 568 (The Stationery Office, London)

Fieldman G, 2013, "Financialisation and ecological modernisation" Environmental Politics early on-line, http://dx.doi.org/10.1080/09644016.2013.821826

Foxon T, 2011, “A coevolutionary framework for analysing a transition to a sustainable low carbon economy" Ecological Economics 70 2258-2267 
Frischtak C, 2011, "O brasil e a economia verde: fundamentos e estratégia de transição" Economia Verde: Desafios e Oportunidades 8 98-110

Garsten C, Jacobsson K, 2007, "Corporate globalisation, civil society and post-political regulation: whither democracy?" Development Dialogue 49 143-157

Geels F, 2010, "Ontologies, socio-technical transitions (to sustainability), and the multi-level perspective" Research Policy 39 495-510

Gibson-Graham K, 2008, "Diverse economies: performative practices for 'other worlds"” Progress in Human Geography 32 613-632

Greenfield O, 2012, "Green Economy Coalition December update", http://www.greeneconomycoalition.org/newsletters/december-update

Hall S, 2010, "Geographies of money and finance I: cultural economy, politics and place" Progress in Human Geography 35 234-245

Hughes A, 2007, "Geographies of exchange and circulation: flows and networks of knowledgeable capitalism" Progress in Human Geography 31 527-535

Kose A M, Prasad E, 2010 Emerging Markets: Resilience and Growth amid Global Turmoil (The Brookings Institution, Washington, DC)

Krueger R, Gibbs D, 2009, "Competitive global city regions and 'sustainable development': an interpretive institutionalist account in the South East of England" Environment and Planning A 42 821-837

Lai K, 2006, “ 'Imagineering' Asian emerging markets: financial knowledge networks in the fund management industry" Geoforum 37 627-642

Lansing D M, 2012, "Performing carbon's materiality: the production of carbon offsets and the framing of exchange" Environment and Planning A 44 204-220

Loh C, 2012 The Green Economy: Pushes and Pulls on Corporate China The Association of Chartered Certified Accountants, London

McCarthy J, 2012, "The financial crisis and environmental governance 'after' neoliberalism" Tijdschrift voor Economische en Sociale Geografie 103 180-195

Marino V, 2011, "Michael F. McNally" The New York Times 27 October, http://www.nytimes.com/2011/10/30/realestate/michael-f-mcnally.html?_r=3

Mouffe C, 2005 On the Political (Routledge, London)

Newell P, Paterson M, 2010 Climate Capitalism: Global Warming and the Transformation of the Global Economy (Cambridge University Press, Cambridge)

Ocampo J A, 2011, "The transition to a green economy: benefits, challenges and risks from a sustainable development perspective: summary of background papers", Report to Second Preparatory Meeting for United Nations Conference on Sustainable Development, Division for Sustainable Development UN-DESA, UNEP, UN Conference on Trade and Development OECD, 2009 Sustainable Manufacturing and Eco-Innovation: Towards a Green Economy, http://www.oecd.org/sti/42944011.pdf

OECD, 2013 Green Growth And Eco-Innovation, http://www.oecd.org/innovation/inno/greengrowthandeco-innovation.htm

Ostrom E, 2010, "Polycentric systems for coping with collective action and global environmental change" Global Environmental Change 20 550-557 
Pearce D, Markyanda A, Barbier E, 1989 Blueprint for a Green Economy (Earthscan, London) Peck J, 2010 Constructions of Neoliberal Reason (Oxford University Press, Oxford)

Prudham S, 2004 Knock on Wood: Nature as Commodity in Douglas-Fir Country (Routledge, Abingdon, Oxon)

Raco M, Lin W, 2012, "Urban sustainability, conflict management, and the geographies of postpoliticism: a case study of Taipei" Environment and Planning C: Government and Policy 30 191-208

Redclift M, 2009, “The environment and carbon dependence: landscapes of sustainability and materiality” Current Sociology 57 369-388

Reuters, 2011, "World Bank to fund small, clean-tech firms \$60 million", 19 October, http://www.reuters.com/article/2011/10/19/us-climate-worldbank-facilityidUSTRE79I28S20111019

Robertson M, Hayden N, 2008, "Evaluation of a market in wetland credits: entrepreneurial wetland banking in Chicago" Conservation Biology 22 636-646

Rotmans J, Kemp R, 2008, "Detour ahead: a response to Shove and Walker about the perilous road of transition management" Environment and Planning A 40 1006-1014

SAM Group, 2011 Cleantech Private Equity: Past, Present and Future, http://www.samgroup.com/images/SAM_Clean_Tech_Study_2011_tcm794-263788.pdf

Scrase I, Smith A, 2009, "The (non) politics of managing low carbon socio-technical regimes" Environmental Politics 18 707-726

Shove E, Walker G, 2007, "CAUTION! Transitions ahead: politics, practice, and transition management" Environment and Planning A 39 763-770

Shove E, Walker G, 2010, "Governing transitions in the sustainability of everyday life" Research Policy 39 471-476

Sidaway J, Bryson J, 2002, “Constructing knowledges of 'emerging markets': UK-based investment managers and their overseas connections" Environment and Planning A 34 401416

Slater D, 2002, "From calculation to alienation: untangling economic abstractions" Economy and Society 31 234-249

Spash C, 2012, "Green economy, red herring” Environmental Values 21 95-99

Spelman C, Cable V, Huhne C, 2011 Enabling the Transition to a Green Economy:

Government and Business Working Together (The Stationery Office, London)

Swyngedouw E, 2009, "The antinomies of the postpolitical city: in search of a democratic politics of environmental production" International Journal of Urban and Regional Research 33 601-620

Swyngedouw E, 2010, "Apocalypse forever? Post-political populism and the spectre of climate change" Theory, Culture and Society 27 213-232

UN, 2012 The Future We Want, https://rio20.un.org/sites/rio20.un.org/files/a-conf.21611_english.pdf.pdf

UNESCO, 2012, “ 'Brazil advocates inclusive green economy’-affirms Antônio Patriota, Brazilian Ministry of Foreign Affairs, in an exclusive interview to UN Brazil”, 15 June, http://www.unesco.org/new/en/rio- 
20/singleview/news/brazil_advocates_inclusive_green_economy_affirms_antonio_patriota_b razilian_ministry_of foreign_affairs in an_exclusive interview to un brazil/\#.U70DWRbf $\underline{\text { Z94 }}$

US Green Building Council, 2011, "The business case for green building", http://www.usgbc.org/DisplayPage.aspx?CMSPageID=2331

USS, 2011, "Climate change", Universities' Superannuation Scheme, 31 August, http://www.uss.co.uk/UssInvestments/Responsibleinvestment/MarketWideInitiativesPublicP olicy/ClimateChange/Pages/default.aspx

Vesilind P A, Harne L, Hendry J, 2006, "The moral challenge of green technology" Trames $1022-31$

Walker G, Shove E, 2007, "Ambivalence, sustainability and the governance of sociotechnical transitions" Journal of Environmental Policy and Planning 9 213-225

Winnett A, Lewis A, 2000, "You'd have to be green to invest in this': popular economic models, financial journalism, and ethical investment" Journal of Economic Psychology 21 319-339 